Natalia E. Kosheleva ${ }^{1 *}$, Nikolay S. Kasimov ${ }^{2}$, Dechingungaa Dorjgotov ${ }^{3}$, Sergey $\mathbf{N}$. Bazha $^{4}$, Dmitryi L. Golovanov ${ }^{5}$, Olga I. Sorokina ${ }^{6}$, Sandag Enkh-Amgalan ${ }^{7}$

${ }^{1}$ Doctor of Science (geography), Leading Research Scientist, Laboratory for Recent Sediments and Pleistocene Paleogeography, Faculty of Geography, M.V. Lomonosov Moscow State University, e-mail: natalk@mail.ru

${ }^{2}$ Academician of the Russian Academy of Sciences, Head of the Department of Landscape Geochemistry and Soil Geography, M.V. Lomonosov Moscow State University, e-mail: secretary@geogr.msu.ru

${ }^{3}$ Academician of the Mongolian Academy of Sciences, Director, Institute of Geography of the Mongolian Academy of Sciences

${ }^{4}$ Ph.D. (biology), Senior Research Associate, A.A.Severtsov Institute of Problems of Ecology and Evolution of the RAS, e-mail: sbazha@inbox.r

${ }^{5}$ Ph.D. (geography), Senior Instructor, Department of Landscape Geochemistry and Soil Geography, M.V. Lomonosov Moscow State University, e-mail:dm_golovanov@mail.ru ${ }^{6}$ Post-graduate student, Department of Landscape Geochemistry and Soil Geography, M.V. Lomonosov Moscow State University

${ }^{7}$ Ph.D, Senior Research Associate, Institute of Geography of Mongolian Academy of Sciences, e-mail: amgalan1969@yahoo.com

* Corresponding author

\title{
ASSESSMENT OF HEAVY METAL POLLUTION OF SOILS IN INDUSTRIAL CITIES OF MONGOLIA
}

\begin{abstract}
This paper presents qualitative and quantitative assessment of technogenic anomalies of heavy metals in urban soils of Ulaanbaatar, Darkhan, and Erdenet (Mongolia), including the assessment of background geochemical conditions of the study area and technological specialization of the cities. The research efforts concentrated on identifying spatial geochemical heterogeneity of urban soils depending upon their functional identity. The ecological status of the urban soils was evaluated based on standards accepted in Mongolia.
\end{abstract}

KEY WORDS: heavy metals, technogenic anomalies, pollution, urban soils, Mongolia
INTRODUCTION

Industrial development in Mongolia during recent decades has led to urban population growth and to aggravation of a number of environmental problems in its cities. Increasing technogenic pressure on the environment caused pollution of air and water, accumulation of pollutants in the soil cover, and deterioration of living conditions of urban residents. Socioeconomic conditions that existed in the early 90's of the 20-th century in the cities of Mongolia have undergone significant changes [Gunin et al., 2003]. The purpose of this study was to establish qualitative and quantitative characteristics of technogenic geochemical anomalies of heavy metals (HM) which are the priority pollutants in the soils of three major industrial centers 
of Mongolia - Ulaanbaatar, Darkhan, and Erdenet.

These cities are located in intermontane valleys and depressions between hills and low mountains of the Hangayn-Hentiyn mountainous area in the Selenga river basin. Ulaanbaatar is the country's capital with a diverse industrial sector. Erdenet is the Mongolian largest production center of enrichment and primary processing of non-ferrous metals (copper and molybdenum). In Darkhan, the industrial sectorincludes primarily ferrous metallurgy and light and construction industries. The sources of pollution in all three cities are associated with thermal power plants (TPP) and ger districts. These entities use brown coal whose combustion products pollute the atmosphere [Kasimov et al., 1995].

The objectives of the research presented herein were to:

- characterize background geochemical parameters of soils in the study region, including the natural geochemical ore anomaly in Erdenet;

- assess general trends of technogenic transformation of micro-elemental composition of urban soils and specific features of soil pollution in different functional zones; and

- carry out environmental-geochemical assessment of HM pollution of the urban soils based on standards accepted in Mongolia.

These objectives were achieved through the ecological-geochemical concept. Basically, the content of chemical elements and their associations was determined in the landscape components (i.e., soil, snow cover, and vegetation) that serve as accumulating media for these chemical substances [Environment geochemistry, 1990; Glazovskaya, 1988; Kasimov, 1995] representing good indicators of pollution and ultimately of environmental change in urban settings.

\section{MATERIALS AND METHODS}

This study used the findings of the Joint Russian-Mongolian Complex Biological Expedition. Soil sampling ${ }^{1}$ was conducted in Ulaanbaatar (99), Darkhan (46), and Erdenet (50) in December 2007. Mixed soil samples were taken by the "envelope" method $(1 \mathrm{~m} \times$ $1 \mathrm{~m})$ from the top sod-humus layer $(0-10 \mathrm{~cm})$ at every $500-800 \mathrm{~m}$ in horizontal direction. In addition, samples of brown coal from three deposits near Ulaanbaatar (Nalaikh, Baganuur, and Chuluut) and of ash from the TPP-3 (provided by the Committee for Air Quality Monitoring of the Ministry of Environmental Protection of Mongolia) were collected.

The bulk content of $\mathrm{Cu}, \mathrm{Zn}, \mathrm{Pb}, \mathrm{Ni}, \mathrm{Co}, \mathrm{Cr}, \mathrm{V}, \mathrm{Mo}$, W, Sn, Ga, Ge, Ti, Mn, Y, Zr, Sn, and Ba in the soil samples was determined by an approximate quantitative spectral method with a spectrograph DFS-465S in the Alexandrov Geological and Geochemical Expedition Laboratory of the Institute of Mineralogy, Geochemistry, and Crystal Chemistry of Rare Elements (IMGRE). Concentrations of $\mathrm{Hg}$ were identified by a portable Zeeman mercury analyzer RA-915+. Basic physical and chemical properties of the soils were defined by routine methods [Orlov, 1985]. To check the accuracy of the approximate quantitative spectral method, the samples of soil, brown coal, and ash were analyzed by mass spectrometry and inductively coupled plasma mass spectrometry (ICP-MS) at the All-Russian Institute of Mineral Raw Materials (VIMS), using devices "Elan-6100" and Optima-4300 DV ("Perkin Elmer", USA). A satisfactory agreement between these methods in determining the concentrations of HM was established.

The analytical data obtained in the study were grouped by functional zones and processed statistically using Statistica 7 software (Mathsoft, 2004). Stable associations of elements in the soils were identified by cluster analysis (Complete Linkage

\footnotetext{
'The number of samples is given in parentheses.
} 
clustering); similarity of $\mathrm{HM}$ behavior was characterized by a correlation coefficient ( $r$ ).

The clarkes of concentration (CC) and dispersion (CD) of HM in background soils were calculated with respect to the global Vinogradov's clarkes [Vinogradov, 1962] used because they occupy an intermediate position between the estimates of Greenwood and Earnshaw [2008] and Bowen [1979]. For the urban soils, the coefficients of concentration $\left(C_{c}\right)$ and dispersion $\left(C_{d}\right)$ of $\mathrm{HM}$ were calculated. Technogenic geochemical specialization of the urban soils was defined by a formula that included metals with $C_{c}>$ 1,5 and whose values are subscribed next to the element symbols. Concentrations of elements in the soils of recreational landscapes in Darkhan and Erdenet were assumed to be reference; in Ulaanbaatar, background conditions were represented by the soils of the Natural Reserve Bogdhan uul and the soils of recreational landscapes.

Ecological-geochemical assessment of the urban soils was based on the integral index of soil pollution

$$
Z c=\sum_{i=1}^{n} K_{c}-(n-1),
$$

where $n$ - number of metals with $C_{c}>1$ [3].

Different levels of soil pollution were described by the following values of $Z c$ : minimum (or low) $(0<Z c<16)$; medium $(16<Z c<32)$; heavy $(32<Z c<64)$; extremely heavy $(64<Z c<128)$; and maximum (Zc $>128)$. Maps on Zc distribution in the urban soils were compiled using the ArcGIS IDW method.

The priority pollutants were identified by comparing the concentrations of elements in the soils with the maximum permissible concentrations (MPC) of elements adopted by the Mongolian National agency of Standards and Measurements [Soil quality, 2008]. Given a relatively even spacing of sampling locations, the percent of area under polluted soils was defined as the ratio of a number of sites where the content of elements exceeded MPC to the total number of tested sites within the city area.

\section{CHARACTERISTICS OF RESEARCH OBJECTS}

Natural conditions. The territory of Ulaanbaatar is located in a wide intermontane basin in the Hentiyn mountainous region with abs. elevations of $1300-1500 \mathrm{~m}$. In the northwestern direction, there are OrkhonSelenga midlands, where elevation falls in the northeasterly direction. This area has flowing forms of relief and broad intermontane valleys with average bottom elevations of 700-1200 m. There, the cities of Erdenet and Darkhan are located. The study region belongs to the Orhon river basin, the largest tributary of the Selenga river. Ulaanbaatar stretches along the Tuul river valley. The city of Darkhan is spread along the Kharaa river valley. Erdenet is located near the Hangalyn-gol river, which is a third-order tributary of the Selenga river. This region has a severely continental climate with large annual and daily fluctuations of air temperatures. The prevailing calm anticyclonic weather conditions in the cities cause temperature inversions in winter, which creates unfavorable ecological environment, specifically, the rise of concentrations of many toxic substances in the air. These toxic elements are gradually deposited into the snow cover and into the upper soil layers.

The light-textured Quaternary sediments with a low content of most trace elements $(C D=1,2 \div 1,5)$ represent the main parent material in the river valleys and intermontane basins [Bathishig, 1999]. In the intermontane depressions, the parent material consists of alluvial-proluvial loamy sediments and sandy loams with inclusions of break stone, gravel, and pebbles. Occasionally, there are outcrops of the Paleogene-Neogene deposits enriched with $\mathrm{Fe}, \mathrm{Mn}$, and $\mathrm{Co}(\mathrm{CC}=1,5 \div 2,6)$. In most cases, the parent bedrocks are composed of granosyenites or metamorphosed Devonian and Carboniferous extrusive-sedimentary rocks (shale rocks). The former are enriched with a complex of lithophylous elements and 
the latter have high concentrations (relative to the global clarke content) of $\mathrm{Fe}, \mathrm{Ti}, \mathrm{Cu}, \mathrm{Ni}$, and $\mathrm{Cr}(\mathrm{CC}=1,7 \div 2,8)$ and a lower content (close to the global clarke content) of $\mathrm{Pb}$, Mo, and V [Bathishig, 1999]. The Erdenet molybdenum copper-porphyritic ore deposit has a high content of $\mathrm{Ag}$ and Re.

The region belongs to the ecotone (i.e., transitional zone) of Southern Siberia and Central Asia, where a unique landscape type, i.e., mountain expositional forest steppe, is widespread. This landscape is manifested on the slopes of the northern exposures (more cold and wet) by forests (often, typical sub-taiga) with the development of seasonally frozen mountain-sod forest soils. Warmer slopes of the southern exposure are occupied by shrub-dry-steppe and by meadow-steppe plant communities that are gradually replaced by dry steppes with sparse thin xerophilous grasslands on the mountainous chernozem and chestnut soils in transition to the flatland. Most of the soils have a low humus (up to $4 \%$ ), but a significant detrital content (and even stoniness) of all soil horizons [6]. Soils of the river valleys are the alluvial sod-lapideous-pebble soils covered with meadow communities and willows and, more rarely, with poplar-larch riparian forests. In the oxbow-shaped lakes, meadow-swampy soils are formed.

Urbanization has caused the destruction of natural vegetation, loss of the sod cover, and reduction of soil turfness leading eventually to the intensification of water and wind erosion, and to the increase of dust content in the atmosphere.

\section{Industries and functional zoning of the}

cities. In Ulaanbaatar, the largest industrial center of Mongolia, the population exceeds one million; the population of Darkhan and Erdenet is 87 and 80 thousand, respectively. Ulaanbaatar has been developing more rapidly for the last 10 years, during which its population has grown 1.6 times and the number of cars has nearly tripled. The central part of Ulaanbaatar, located on the right bank of the river Tuul, is a place of modern many-storeyed residential, administrative, and commercial buildings. Most of its industrial enterprises and all TPPs are located in the western part of the city, which, in combination with the predominance of western and northwestern wind bearings, causes soil pollution in its eastern and southeastern parts. The ger districts surround the central districts of the city creeping up the slopes of southern, southwestern, and southeastern foothills of the Baga-Khentei Range.

Darkhan stretches along the river Kharaa valley for 12 miles from north to south. The industrial zone is located in the southern and southeastern parts of the city, where there are the TPP and the cement, wood processing, leather tanning, and iron-steel plants. The industrial zone is separated from the main (new) part of the city by an upland spur. The old part of the city with its railway station and the elevator is located in the north. The ger districts occupy the eastern, western, and northern outskirts of the city.

Erdenet (as well as Ulaanbaatar) is located in the intermontane basin that stretches from southwest to northeast. The principal industries of the city, i.e., a copper and molybdenum porphyritic ore mining and concentrating complex (MCC) and waste rock dumps, are located in its the eastern and northeastern parts. North of the mine, the extraction plant abuts a mining and concentrating factory, two TPPs, and a complex of industrial facilities. Further north in the valley of a tributary of the Hangalyngol river, there are sludge pits. The central part of modern residential districts and administrative buildings is located to the west of the industrial zone. The ger districts are in the southwestern part of the city on the upland slopes. Military bases and ranges are in the city's southwest part.

The TPPs and ger stoves, which burn brown coal, are the main sources of pollution. Analysis of micro-elemental composition of the brown coal and the TPP-3 ash in Ulaanbaatar, obtained by the ICP-MS method, 
Table 1. Geochemical specialization of Mongolian coals and fly ash from the TPP-3

\begin{tabular}{|c|c|c|c|}
\hline Study facilities & $\begin{array}{c}\text { Relative to clarkes } \\
\text { of lithospheric concentrations } \\
\text { based on Vinogradov [12] }\end{array}$ & $\begin{array}{c}\text { Relative to the average } \\
\text { for world coals (a) and coal } \\
\text { ash (b) [13] }\end{array}$ & $\begin{array}{c}\text { Relative } \\
\text { to TPP-3 fly ash }\end{array}$ \\
\hline $\begin{array}{c}\text { Ulaanbaatar coals } \\
\text { (average) }\end{array}$ & $\mathrm{Se}_{333} \mathrm{Sb}_{13} \mathrm{Bi}_{12} \mathrm{~W}_{2,1} \mathrm{Be}_{2} \mathrm{Mo}_{1,8} \mathrm{~Pb}_{1,6}$ & $\mathrm{~Pb}_{23} \mathrm{Sb}_{16} \mathrm{Se}_{4,2} \mathrm{Cu}_{3,6} \mathrm{Bi}_{2,3} \mathrm{Ni}_{1,3}(a)$ & $\mathrm{Sb}_{3,4} \mathrm{Se}_{2,6} \mathrm{Hg}_{2,5} \mathrm{Bi}_{1,8} \mathrm{Te}_{1,6}$ \\
TPP-3 fly ash & $\begin{array}{c}\mathrm{Se}_{128} \mathrm{~W}_{100} \mathrm{Be}_{32} \mathrm{Mo}_{13} \mathrm{Bi}_{6,5} \mathrm{Th}_{6,5} \mathrm{As} \\
\mathrm{Cd}_{4} \mathrm{Sb}_{3,7} \mathrm{Cu}_{3,7} \mathrm{U}_{3,1} \mathrm{Sr}_{3} \mathrm{Co}_{3} \mathrm{Sn}_{1,8} \mathrm{~Pb}_{1,7}\end{array}$ & $\mathrm{~W}_{5} \mathrm{Th}_{4,2} \mathrm{U}_{2} \mathrm{Cu}_{1,7}($ b) & - \\
\hline
\end{tabular}

revealed a wide range of contaminants of the urban landscapes associated with thermal generation (Table 1). The brown coal deposits near Ulaanbaatar, as in the case of most sulfur coals, have a high content of chalcophylic elements ( $\mathrm{Se}, \mathrm{Sb}, \mathrm{Cu}, \mathrm{Bi}$, $\mathrm{Pb})$, and $\mathrm{W}, \mathrm{Be}$, and Mo, i.e., elements that characterize the geochemical specialization of a coal-bearing basin. The fly ash is rich in natural radioactive elements Th and $U$. The ratio of micro-elemental concentrations in the coals to these of the TPP-3 ash (Table 1) allowed us to identify elements that are depleted in the ash and that may be transitioning to the gaseous phase: $\mathrm{Se}, \mathrm{Sb}, \mathrm{Hg}, \mathrm{Te}, \mathrm{Bi}$, and possibly, $\mathrm{Pb}$. These elements do not accumulate in the solid phase and are spread into the atmosphere creating the direct negative impact on human health.

\section{RESULTS AND DISCUSSION}

Regional soil geochemical background conditions and their transformation in the major industrial centers. The extent of technogenic geochemical transformation of the urban soils was determined by analyzing chemical composition of dark chestnut soils in the natural and recreational landscapes and by constructing their geochemical spectra (Fig. 1, a). The reference characteristics for the three cities were close in respect to most metals; they tend to approach the global clarke concentrations for $\mathrm{Zn}, \mathrm{Mn}, \mathrm{V}, \mathrm{Ti}, \mathrm{Cr}$, $\mathrm{Zr}, \mathrm{Hg}$, and $\mathrm{Ba}$ and are below the global clarke concentrations for $\mathrm{Ge}, \mathrm{Co}, \mathrm{Y}$, and $\mathrm{Ni}$ $(C D=1,7 \div 8,4)$. In Ulaanbaatar, the significant accumulation above the clarke concentrations were noted only for $\mathrm{W}(C \mathrm{CC}=1,5)$, and for $\mathrm{Pb}$, $\mathrm{Sn}, \mathrm{Mo}$, and $\mathrm{Ag}(C C=1,9 \div 1,5)$ in Darkhan. The ore-geochemical specialization of the area of the Erdenet copper-molybdenum deposit is manifested in high contents of $\mathrm{Mo}, \mathrm{Cu}$, and $\mathrm{Ag}(\mathrm{CC}=8,2 \div 2,8)$.

Industrial activity is the other main source of HM accumulation in the urban soils (Fig. 1, b). In Ulaanbaatar, a multi-elemental geochemical anomaly with relatively low clarke concentrations $\left(\mathrm{Ag}_{3,0} \mathrm{~Pb}_{2,4} \mathrm{Sn}_{2,1} \mathrm{Hg}_{1,9} \mathrm{Ge}_{1,7} \mathrm{Zn}_{1,7} \mathrm{~W}_{1,5}\right)$ was formed. Its formation may be attributed to the diversification of the city's industry and the predominance of light-textured soils with a low sorption capacity. Soil pollution in Darkhan $\left(\mathrm{Cr}_{5,0} \mathrm{Hg}_{3,1} \mathrm{~W}_{3,0}\right)$ indicates its narrow industrial specialization, primarily in leather tanning, gold mining, and thermal power production. The soils of Erdenet accumulated $\mathrm{Mo}_{2,2} \mathrm{Cu}_{1,8} \mathrm{Sn}_{1,5} \mathrm{Ge}_{1,5}$. The sources of these elements are the MCC rock waste dumps blown by the wind and enriched with $\mathrm{Cu}$ and $\mathrm{Mo}$ and the combustion products of brown coal containing high content of $\mathrm{Sn}$ and Ge.

According to the results of the cluster analysis, the reference soils have the most stable associations of elements which reflect geochemical characteristics of the parent material: $\mathrm{Cu}-\mathrm{Zn}-\mathrm{Pb}, \mathrm{Mn}-\mathrm{Ba}$, $\mathrm{Cr}-\mathrm{Ga}$, and $\mathrm{Y}-\mathrm{Zr}$. The first association combines cationgenic and chalcophylic elements of poor mobility in neutral and alkaline conditions that accumulate in the humus horizons. The second association includes $\mathrm{Mn}$, which hydroxides represent the sorption barrier for Ba. The third and the fourth associations include complexforming elements. Comparison of the HM associations in the three cities showed their considerable variability due to the differences in the natural and 
a)

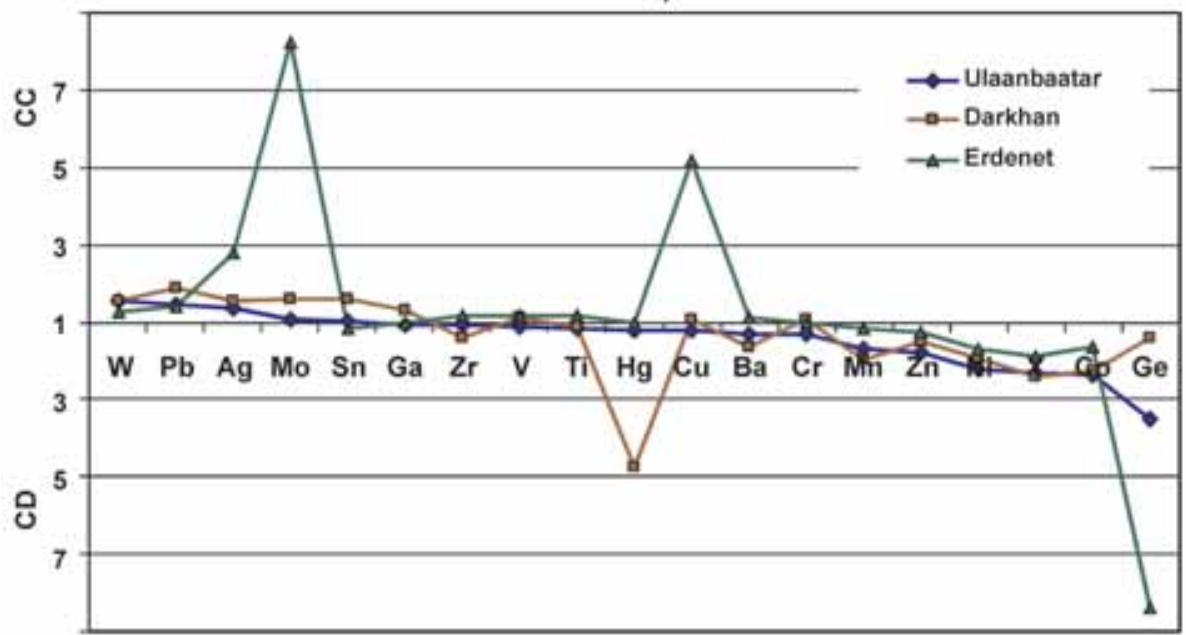

b)

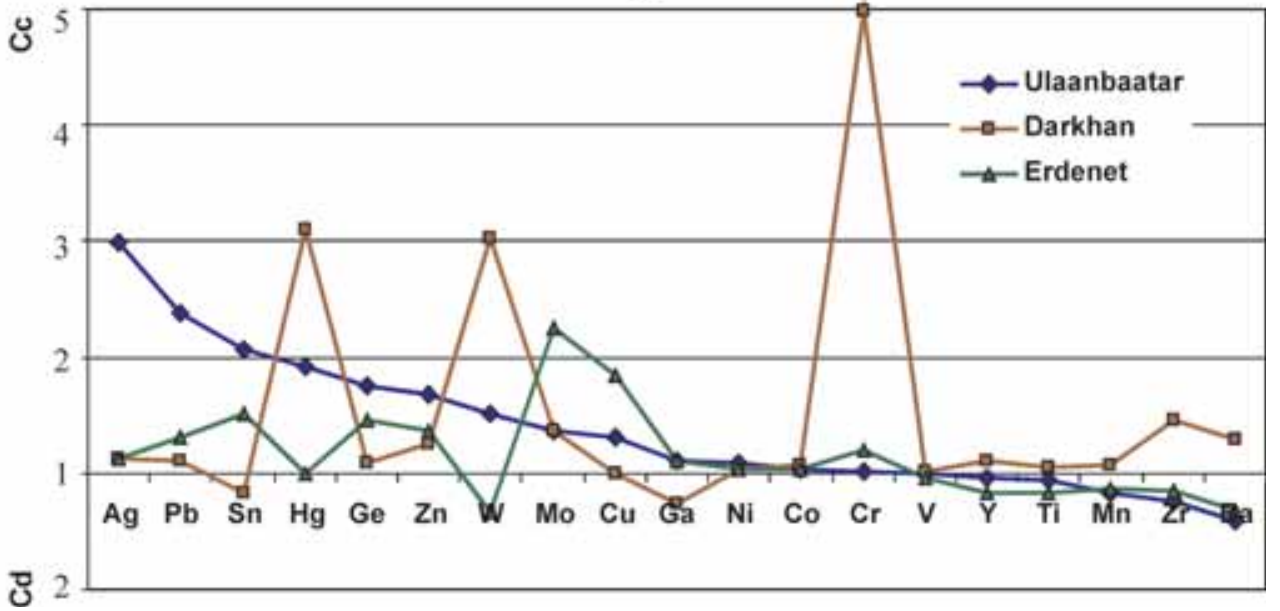

Figure 1. Geochemical specialization of the soils in Ulaanbaatar, Dakhan, and Erdent: background (a) and technogenic (b). The clarkes of concentration (CC) and dispersion (CD) in the background soils were estimated with respect to the Vinogradov's clarkes; the coefficients of concentration (Cc) and dispersion (Cd) were estimated with respect to the background soils.

anthropogenic conditions within the urban areas (Table 2).

\section{The spatial geochemical heterogeneity} of the urban soils. Geochemical heterogeneity of the urban soils is associated with the functional identity of the territories. The main elements of this functional composition are the highways, traditional ger districts, many-storeyed residential blocks, and recreational and industrial zones. For these sectors, the average concentrations of $\mathrm{HM}$ and the parameters of variability were calculated. In addition, the associations of elements were defined and geochemical spectra were plotted. Table 3 provides average concentrations of metals - the priority pollutants in the soils of these zones.

In Ulaanbaatar, the highest level of accumulation of many elements-pollutants is confined to the soils near the major highways and many-storeyed residential 
Table 2. Associations of HM in the upper horizons of background and urban soils

\begin{tabular}{|c|c|c|c|}
\hline $\begin{array}{l}\text { Types of landscapes } \\
\text { (number of samples) }\end{array}$ & Association, correlation coefficient $(r)$ & $\begin{array}{c}\text { No } \\
\text { association }\end{array}$ & $\begin{array}{l}\text { Significant } r \\
(P=95 \%)\end{array}$ \\
\hline \multicolumn{4}{|c|}{ Ulaanbaatar } \\
\hline Background, recreational (10) & $\begin{array}{c}\mathrm{Cu}, \mathrm{Pb}, \mathrm{Zn}, \mathrm{V}, \mathrm{Sn}, \mathrm{B}(0,68-0,88) ; \\
\mathrm{Cr}, \mathrm{Li}, \mathrm{Ni}, \mathrm{Ga}, \mathrm{Co}(0,78-0,92) ; \mathrm{Mn}, \mathrm{Y}, \mathrm{Zr}, \mathrm{Ba}(0,85-0,97)\end{array}$ & $\begin{array}{l}\text { Ag, } \mathrm{Mo}, \mathrm{Hg} \\
\mathrm{Ti}, \mathrm{Sr}\end{array}$ & 0,63 \\
\hline $\begin{array}{l}\text { Residential, industrial, and } \\
\text { traffic zones(83) }\end{array}$ & $\begin{array}{c}\mathrm{Cu}, \mathrm{Zn}, \mathrm{Pb}(0,59-0,72) ; \mathrm{Ni}, \mathrm{Co}, \mathrm{Ga}, \mathrm{B}(0,48-0,81) ; \\
\mathrm{Cr}, \mathrm{V}(0,73) ; \mathrm{Mn}, \mathrm{Ti}, \mathrm{Y}(0,44-0,64) ; \mathrm{Sr}, \mathrm{Ba}, \mathrm{Zr}(0,56-0,59)\end{array}$ & $\begin{array}{l}\mathrm{Ag}, \mathrm{Mo}, \mathrm{Hg} \\
\mathrm{Sn}, \mathrm{Li}\end{array}$ & 0,28 \\
\hline \multicolumn{4}{|c|}{ Darkhan } \\
\hline $\begin{array}{l}\text { Residential, industrial, and } \\
\text { traffic zones (42) }\end{array}$ & $\begin{array}{c}\mathrm{Cu}, \mathrm{Zn}, \mathrm{Pb}, \mathrm{Sn}, \mathrm{Ga}(0,57-0,83) ; \mathrm{Ni}, \mathrm{V}, \mathrm{B}, \mathrm{Co}, \mathrm{Ti}(0,35-0,75) ; \\
\mathrm{Mo}, \mathrm{W}, \mathrm{Ge}(0,74-0,85) ; \mathrm{Zr}, \mathrm{Y}, \mathrm{B}(0,33-0,63)\end{array}$ & $\begin{array}{l}\mathrm{Cr}, \mathrm{Ag}, \mathrm{Mn} \\
\quad \mathrm{Hg}, \mathrm{Li}\end{array}$ & 0,31 \\
\hline \multicolumn{4}{|c|}{ Erdenet } \\
\hline Background, recreational (8) & $\begin{array}{c}\mathrm{Cu}, \mathrm{Ag}, \mathrm{Ge}, \mathrm{Zn}, \mathrm{Pb}(0,78-0,9) ; \\
\mathrm{Cr}, \mathrm{V}, \mathrm{Ga}(0,91-0,96) ; \mathrm{Mo}, \mathrm{Sn}(0,73) ; \mathrm{Mn}, \mathrm{Ba}(0,89) ; \\
\text { Ti, Y, Zr }(0,68-0,87)\end{array}$ & $\begin{array}{c}\text { W, Co, Hg } \\
\text { Li, B }\end{array}$ & 0,71 \\
\hline $\begin{array}{l}\text { Residential, industrial, and } \\
\text { traffic zones (39) }\end{array}$ & $\begin{array}{l}\mathrm{Cu}, \mathrm{Ag}, \mathrm{Mo}(0,76-0,92) ; \mathrm{Pb}, \mathrm{V}, \mathrm{B}, \mathrm{Ga}, \mathrm{Ge}, \mathrm{Zn}(0,28-0,66) ; \\
\mathrm{Ni}, \mathrm{Co}, \mathrm{Li}(0,63-0,84) ; \mathrm{Mn}, \mathrm{Ba}, \mathrm{Ti}, \mathrm{Y}, \mathrm{Zr}, \mathrm{Sn}(0,29-0,77)\end{array}$ & $\mathrm{Cr}, \mathrm{W}, \mathrm{Hg}$ & 0,34 \\
\hline
\end{tabular}

blocks in the old part of the city (Fig. 2), where high concentrations of $\mathrm{Pb}, \mathrm{Hg}, \mathrm{Ag}$, $\mathrm{Zn}, \mathrm{W}, \mathrm{Ge}, \mathrm{Mo}, \mathrm{Sn}$, and $\mathrm{Cu}\left(\mathrm{C}_{\mathrm{c}}=3 \div 1,5\right)$ are present. In the industrial zone, the $C_{c}$ is about 0,5 units lower due to a larger area of dispersion of emissions released from the pipes to the atmosphere at a considerable height. The least polluted areas are the ger districts on the slopes in the outlying parts of the city. Despite a relatively young age of development in these areas, there is a noticeable accumulation of $\mathrm{Pb}$ and Ge from the products of incomplete combustion of brown coal used for ger heating.

The most stable associations of elements traced in the soils of almost all functional zones of the city are $\mathrm{Cu}-\mathrm{Zn}-\mathrm{Pb}, \mathrm{Ni}-\mathrm{Co}-\mathrm{Ga}$, $\mathrm{Cr}-\mathrm{V}, \mathrm{Mn}-\mathrm{Ti}$, and $\mathrm{Ba}-\mathrm{Zr}$. The first association combines elements from the anthropogenic sources, primarily from motor vehicles. The second and the third associations include elements that accumulated in the clay and fine-silt fractions. Their variations depend upon the heterogeneity of soil texture. The fourth and the fifth associations mainly reflect geochemical features of the parent material of valleys and terraces common in the city's area.
In the soils of Darkhan, the widest spectrum of elements-pollutants $\left(\mathrm{W}_{15} \mathrm{Cr}_{8,8} \mathrm{Hg}_{2,6} \mathrm{Ge}_{1,9} \mathrm{Mo}_{1,9} \mathrm{Zr}_{1,5}\right)$ was found in the industrial zone (see Fig. 2). The soils of the ger districts have the following formula of technogenic geochemical specialization: $\mathrm{W}_{9,1} \mathrm{Zn}_{1,8} \mathrm{Mo}_{1,7} \mathrm{Hg}_{1,5}$. There is a noticeable accumulation of $W_{8,6} \mathrm{Hg}_{2,7} \mathrm{Ge}_{1,5} Z_{n_{1,5}}$ in the soils of new residential areas. Geochemical transformation of Darkhan soils is manifested in elemental associations, the most stable of which are: $\mathrm{Cu}-\mathrm{Zn}-\mathrm{Pb}, \mathrm{Mo}-\mathrm{W}-\mathrm{Ge}$, Sn-Ga, Zr$\mathrm{Y}-\mathrm{Ba}$, Ni-V, and $\mathrm{Co}-\mathrm{Ti}$. Undoubtedly, the first three associations are of the technogenic origin from the area-source pollution. The most hazardous metals, i.e., $\mathrm{Cr}, \mathrm{Ag}$, and $\mathrm{Hg}$, did not form stable associations, which can be explained by the point nature of pollution.

In the Erdenet soils, the most contrasting technogenic anomaly is confined to the traditional ger districts (see Fig. 2), where $\mathrm{Sn}_{2,6} \mathrm{Ge}_{2,4} \mathrm{Zn}_{1,7} \mathrm{Cu}_{1,6} \mathrm{Mo}_{1,5}$ were accumulating. Soils of the industrial zone accumulated $\mathrm{Cu}_{1,8} \mathrm{Mo}_{1,5}$, while soils of the many-storeyed residential blocks accumulated $\mathrm{Ge}_{2,2} Z_{2,0}$. For the traffic zone, the accumulation of elements-pollutants was not identified, 


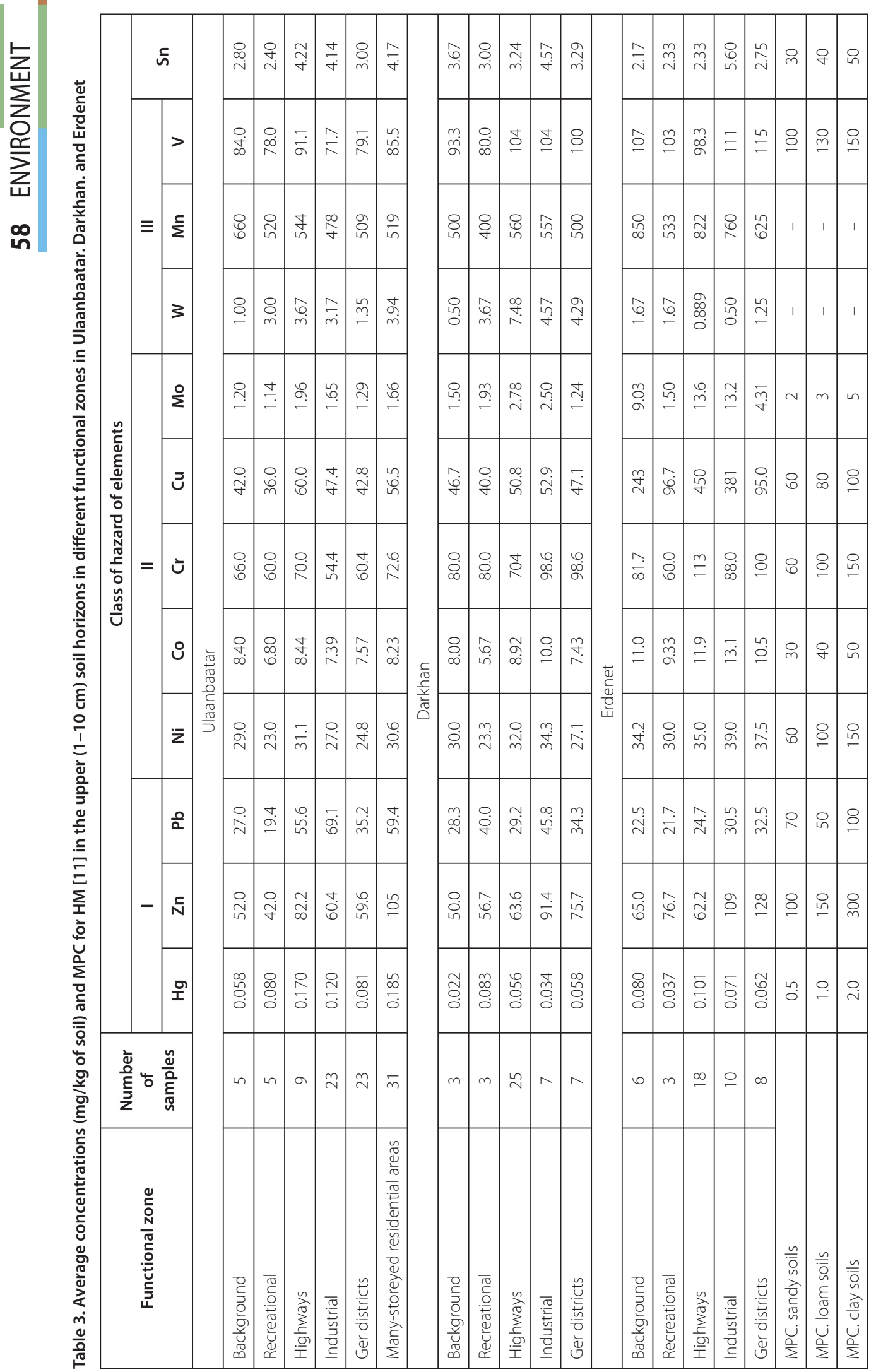



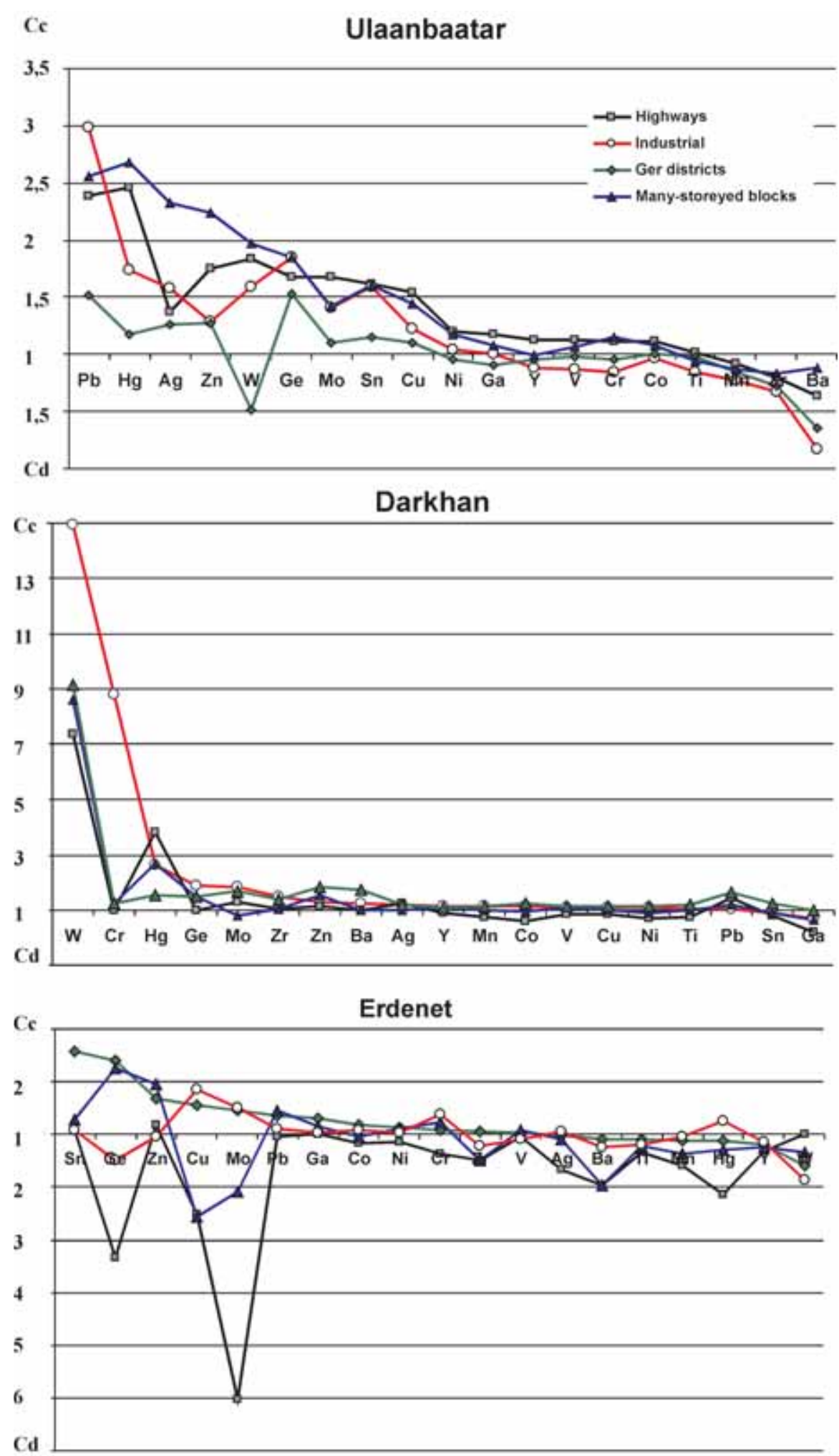

Figure 2. HM concentrations in the upper soil horizons of different functional zones in Ulaanbaatar, Darkhan, and Erdenet. 

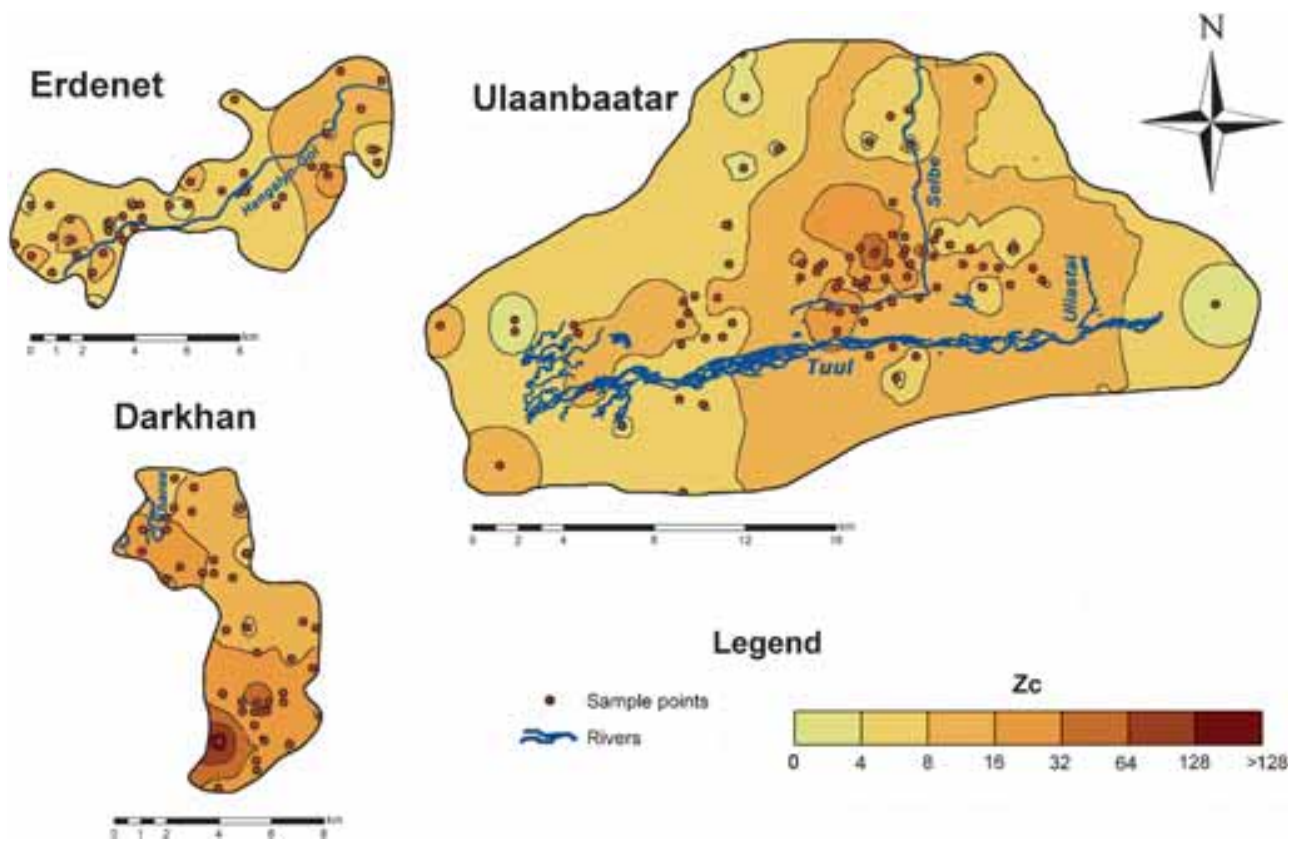

Figure 3. Maps of the integral index of soil pollution Zc for the soils in the cities of Ulaanbaatar, Darkhan, and Erdenet.

which may be attributed to the location of the highway system in the transitional geochemical environment, i.e., on the slopes of the river valley. Specific (for each functional zone) associations of elements characterize the geochemical heterogeneity of the Erdenet soils. The most stable associations are those that reflect the character of the parent material: $\mathrm{Cu}-\mathrm{Ag}-\mathrm{Mo}$ (ore body) and $\mathrm{Mn}-\mathrm{Ba}-\mathrm{Ti}-\mathrm{Y}-\mathrm{Zr}$ (granitoids). The industrial pollution is manifested in the $\mathrm{Pb}-\mathrm{Zn}$ association.

The ecological-geochemical assessment of pollution of the urban soil. The values of the integral index of soil pollution Zc in Ulaanbaatar and Erdenet are low in all functional zones: in Ulaanbaatar, Zc varies from 5,6 (recreational zone) to 18 (manystoreyed residential blocks), while in Erdenet, it varies from 1,53 (major highways) to 8,2 (ger districts) due to enhanced reference concentrations of some HM. The highest values ofZc were found in the soils of Darkhan. In the residential and traffic zones, Zc ranges from 12,6 to 14,4 , while in the industrial zone it reaches 27,7 which corresponds to the medium level of pollution.
The maps on Zc distribution (Fig. 3) demonstrate specific features of soil pollution in the urban areas studied. The bulk of the Ulaanbaatar soils belongs to the category of low-polluted soils (Zc $<16)$. In the city's center, in some locations, relatively high values of pollution were identified (Zc up to 40). In Edernet, the soils are less polluted (Zc $<16)$, with the exception of several locations near the MCC and in the ger district (Zc reaching 37). In Darkhan, the northern part with the residential blocks and some factories has a medium soil pollution level. In the central part of this city with the modern many-storeyed buildings, the level of pollution is low. In the southern part, i.e. in the industrial zone predominantly, Zc increases to 64 with some local maximums reaching 200.

The environmental risk of soil pollution in Ulaanbaatar, Darkhan, and Erdenet, was assessed by comparing the HM concentrations in the upper soil horizons with the rather stringent official Mongolian sanitary-hygienic standards [Soil quality, 2008] that vary depending upon soil texture 


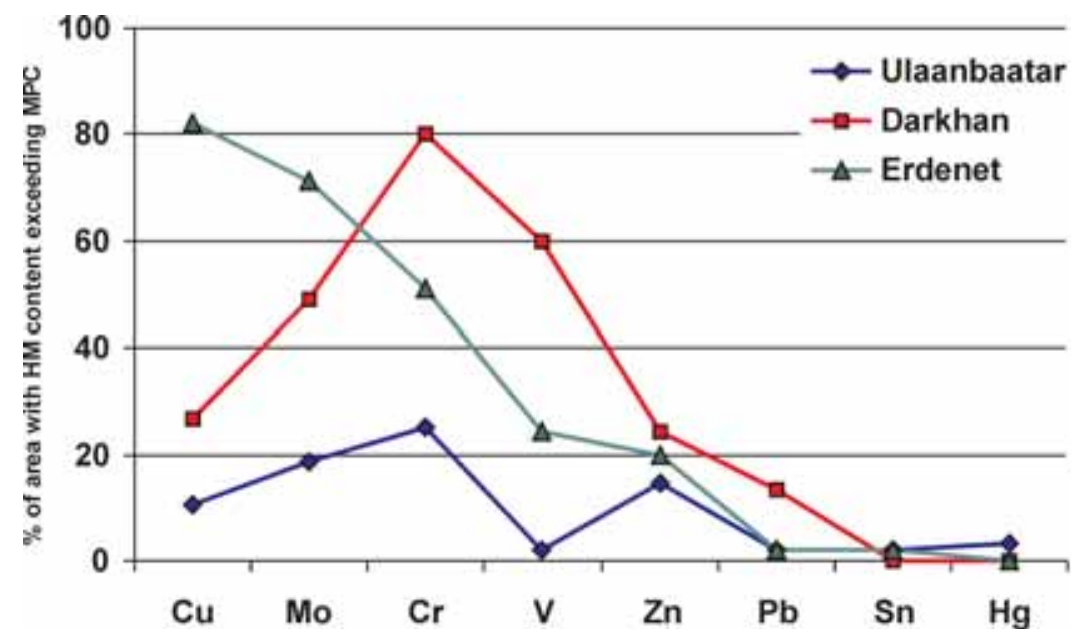

Figure 4. The assessment of ecological hazard from HM pollution in Ulaanbaatar, Darkhan, and Erdenet (\% of area with HM content in soils exceeding MPC).

(see Table 3). It appeared that in Ulaanbaatar, the MPC values are exceeded only in the cases of $\mathrm{Cr}$ (on $25 \%$ of the territory), Mo (19\%), Zn (15\%), and Cu (10\%) (Fig. 4). The areas of soil pollution are mostly confined to the residential (modern and ger districts alike) and traffic zones.

In two other cities, the share of soils affected by pollution (that exceeds MPC) is more significant: most hazardous pollutants in Darkhan are (in \% of the total area of the city): Cr (80\%), V (60\%), Mo (49\%), Cu (27\%), Zn (24\%), and Pb (13\%); in Erdenet Cu (82\%), Mo (71\%), Cr (51\%), V (24\%), and Zn (20\%). In Darkhan, the most polluted zones are the ger districts and the industrial zones, while in Erdenet the most polluted zones are the ger districts, many-storeyed residential blocks, and industrial zones.

\section{CONCLUSIONS}

1. The background geochemical specialization of the soils in the region is associated with close to or below the clarke values concentrations of most trace elements. The exceptions are: in Ulaanbaatar - W $(C C=1,5)$ and $\mathrm{Pb}, \mathrm{Sn}, \mathrm{Mo}, \mathrm{Ag}$, and W $(C C=1,9 \div 1,5)$ in Darkhan. The most pronounced natural geochemical anomaly was found in the soils of Erdenet: Mo $(C C=8,2)$, $C u(5,2)$, and $\operatorname{Ag}(2,8)$.
2. The technogenic geochemical specialization of Ulaanbaatar - $\mathrm{Ag}_{3,0}$ $\mathrm{Pb}_{2,4} \mathrm{Sn}_{2,1} \mathrm{Hg}_{1,9} \mathrm{Ge}_{1,7} \mathrm{Zn}_{1,7} \mathrm{~W}_{1,5} \quad$ - reflects the influence of many different sources of soil pollution. The widest spectrum of elements-pollutants is present in the soils of the many-storeyed residential blocks and near the major highways. The geochemical specialization of Darkhan soils is the product of $\mathrm{Cr} 5, \mathrm{OHg} 3,1 \mathrm{~W} 3,0$ pollution from leather tanning, gold mining, and TPP. Abnormally high levels of accumulation of $\mathrm{W}$ and $\mathrm{Cr}$ in the soils are confined to the industrial areas; the residential and traffic zones accumulate $\mathrm{W}$ and $\mathrm{Hg}$. The anthropogenic accumulation of Mo2,2Cu1,8Sn1,5Ge1,5 in the soils of Erdenet is associated with mining of copper and molybdenum ores and burning of brown coal. The most pronounced technogenic anomaly of $\mathrm{Sn}, \mathrm{Ge}, \mathrm{Zn}, \mathrm{Cu}$, and Mo is present in the soils of the ger districts, while in the area of many-storeyed residential blocks, the excess over the reference values was observed only for Ge and Zn.

3. In Ulaanbaatar, the magnitude of technogenic geochemical anomalies manifested by Zc values, reaches its maximum $(18,0)$ in the soils of many-storeyed residential blocks. The greatest expression of the anomalies was noted in Darkhan: $Z C=17,7$ (industrial zone) and 12,6 and 
14,5 (residential and traffic zones). In Erdent, almost everywhere, the Zc values do not exceed the value of 10 due to the elevated reference concentrations of some HM. The ecological conditions of the urban soils are characterized by the increase over the MPC levels for $\mathrm{Cr}, \mathrm{Mo}, \mathrm{Zn}$, and $\mathrm{Cu}$ within 15-20\% of the Ulaanbaatar area. In the other two cities, the situation is more dangerous: 50 $80 \%$ of the Darkhan territory has $\mathrm{Cr}, \mathrm{V}$, and Mo concentrations in excess of the MPC; the concentrations of $\mathrm{Cu}, \mathrm{Mo}$, and $\mathrm{Cr}$ exceed the MPC in Erdenet.

\section{ACKNOWLEDGEMENTS}

This research was funded by the Russian Foundation for Basic Research (RFBR) (project 10-05-93178-Мoнг_a) and by the Federal Target Program "Research and ScientificPedagogical Cadres of Innovative Russia, 2009-2013" (project П1078).

\section{REFERENCES}

1. Bathishig, O. (1999) Soil geochemical characteristics of the Tuul river valley: Candidate dissertation abstract. Ulaanbaatar, $24 \mathrm{p}$.

2. Bowen H.J.M. (1979) Environmental Chemistry of the Elements. N.Y.: Acad. Press, 333 p.

3. Environmental geochemistry. (1990) Moscow: Nedra, 332 p.

4. Glazovskaya, M.A. (1988) Geochemistry of natural and anthropogenic landscapes. Moscow: Higher Education, 350 p.

5. Greenwood, N.N. and A. Earnshaw. (2008) Chemistry of the elements. In two volumes. Moscow: Binom.

6. Ground vegetation and soils of Mongolia. (1984) Moscow: Nauka, 191 p.

7. Gunin, P.D., A.K. Evdokimova, S.N. Bazha, and M. Sandar. (2003) Social and environmental problems of the Mongolian ethnos in urban areas. UlaanBaatar-M., pp. 61-95.

8. Kasimov, N.S. (1995) Methodology and methods of landscape-geochemical analysis of urban areas / Ecogeochemistry of urban landscapes. M.: Moscow State Univ. Press, pp. 6-39.

9. Kasimov, N.S., M.Y. Lychagin, A.K. Evdokimova, D.L. Golovanov, and Y.I. Pikovsky. (1995) Ulaanbaatar, Mongolia (thermal energy sector). Intermountain basin / Ecogeochemistry of urban landscapes, N.S. Kasimov (Ed.). M.: Moscow State Univ. press, pp. 231-248.

10. Orlov, D.S. (1985) Soil Chemistry. M.: Moscow State Univ. press, 376 p.

11. Soil quality. Soil pollutants, maximum permissible concentrations. (2008) Mongolian National agency of Standards and Measurements. Ulaanbaatar. 8 p.

12. Vinogradov, A.P. (1962) The average content of chemical elements in the principal types of igneous rocks of the Earth's crust // Geochemistry. № 7, pp. 555-472.

13. Yudovich, Y.E. and M.P. Ketris. (2005) Toxic trace elements in fossil coals. Ekaterinburg: Ural Branch of the RAS, $655 \mathrm{p}$. 


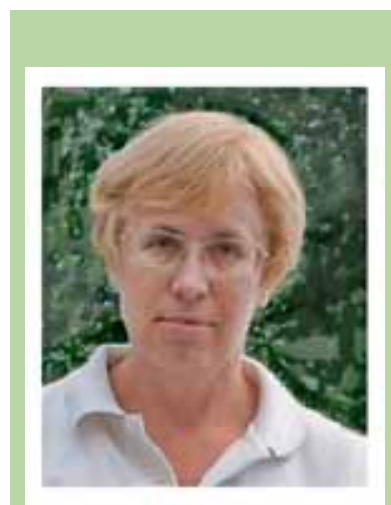

Natalia E. Kosheleva graduated from two Faculties of M.V. Lomonosov Moscow State University (MSU): the Faculty of Geography (1976) and the Faculty of Computational Mathematics and Cybernetics (1980). Since 1995, she is Leading Research Scientist in the Department of Landscape Geochemistry and Soil Geography, the Faculty of Geography, MSU. She received her Ph.D. (geography) in 1982 and Doctor of Science degree in 2004. N.E. Kosheleva is a reputed expert in the field of mathematical methods and modelling of landscape-geochemical systems. Recently, she has being focusing her research efforts on urban environmental problems, specifically on pollution of urban landscapes. She published nearly 150 scientific works. Main publications: Modeling of Soils and LandscapeGeochemical Processes. Study Book. Moscow, Moscow Univ. Press, 1997. 109 p.; a series of papers in the "Soil Science" and "Moscow State University Bulletin" magazines (with N.S. Kasimov, E.M. Nikiforova et al.) on geochemistry of natural and urban soil-plant systems.

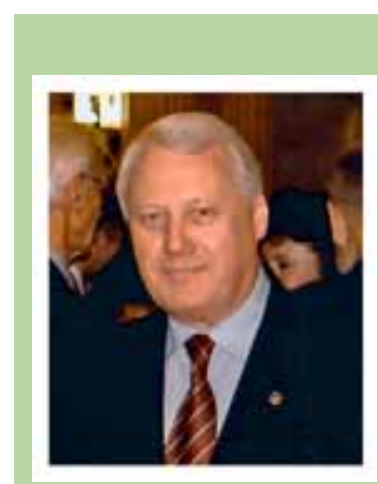

Nikolay S. Kasimov received his Ph.D. (geography) studying landscape geochemistry of fault zones in 1972 and his Doctor of Science degree (1983) in the field of paleogeochemistry of steppes and deserts landscapes. Since 1987, he has been Head of the Department of Landscape Geochemistry and Soil Geography; since 1990 - Dean of the Faculty of Geography at M.V. Lomonosov Moscow State University. His current research interests are: geochemistry of landscapes, paleogeochemistry, and geochemistry of urban and aquatic landscapes. He is the author of about 300 scientific works, including: Landscape Geochemistry of Steppe and Desert Landscapes, 1988; Ecogeochemistry of Urban Landscapes, 1995 (author and editor); Landscape Geochemistry, 1999 (co-author A.I. Perel'man); Oil and Environment of Kaliningrad Region; 2008 (author and editor).

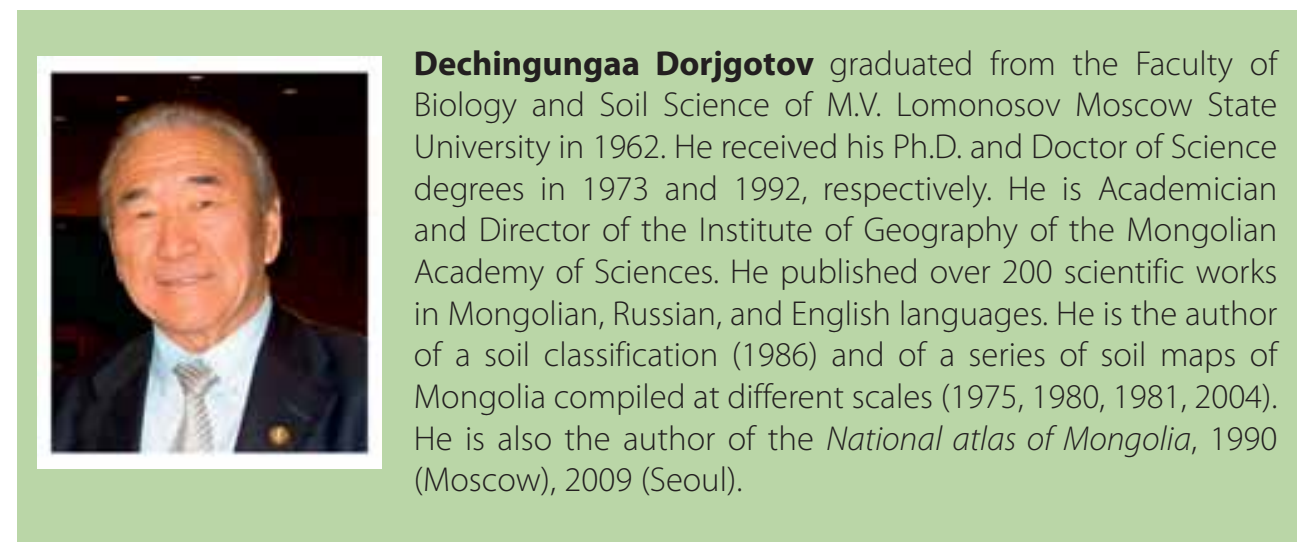




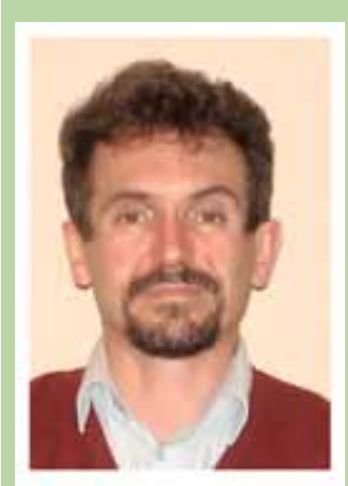

Sergey N. Bazha graduated in economics from the University of Agricultural Sciences, Hungary, in 1989. In 1993, he finished postgraduate studies at the Institute of Economics, Moscow. In March of 1998, he became Research Assistant and in 2002 Senior Research Associate at the A.N. Severtsov Institute for Ecology and Evolution of the RAS, Moscow, where he received his Ph.D. in ecology in 2002. His primary research interests are focused on ecological risks, environmental pollution, plant-soil degradation, and ecological mapping. Main publications: Gunin P.D., A.K. Evdokimova, S.N. Bazha, and M. Saandar. Social and Ecological Problems of Mongolian Ethnic Community in Urbanized Territories. 2003. Ulaanbaatar-Moscow. Rosselkhozacademic Publ. 96 p.; Gunin, P.D. and S.N. Bazha. Ecological Assessment of Degradation Processes in the Mongolian Part of the Baikal Basin / Monograf Conserving Biodiversity in Arid Regions. Kluwer Acad. Publ. 2003. p. 157-177; Gunin P., E. Vostokova, S. Bazha, A. Prischepa, I. Miklyaeva, R. Tateishi, and Ch. Dugarjav. Present-Day Ecosystems of the Selenga River Basin and Factors of their Destabilization. CEReS, Chiba University. Japan. 2006. 139 p.

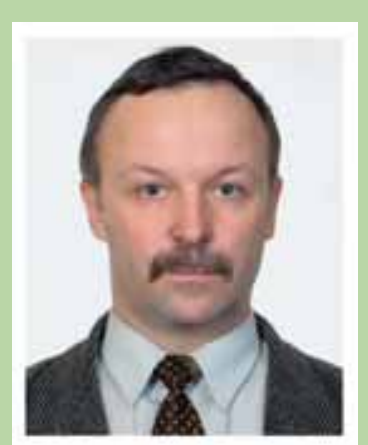

Dmitryi L. Golovanov graduated from the Department of Landscape Geochemistryand Soil Geography of M.V.Lomonosov Moscow State University in 1984 and has being working in this department since that time. Currently, he holds a position of Senior Lecturer. He received his Ph.D. in 2004; his dissertation was devoted to oasis-type soil-forming processes in extreme arid deserts of Mongolia. The area of his scientific interest covers genesis, geography, and mapping of soils and ecologicalgeochemical assessment. Main publications: Ecogeochemistry of Urban Landscapes (1995, with co-authors); a series of papers on arid and salinized soils in the "Soil Science" magazine (with Yamnova, I.A., M.P. Verba, and E.I. Pankova).

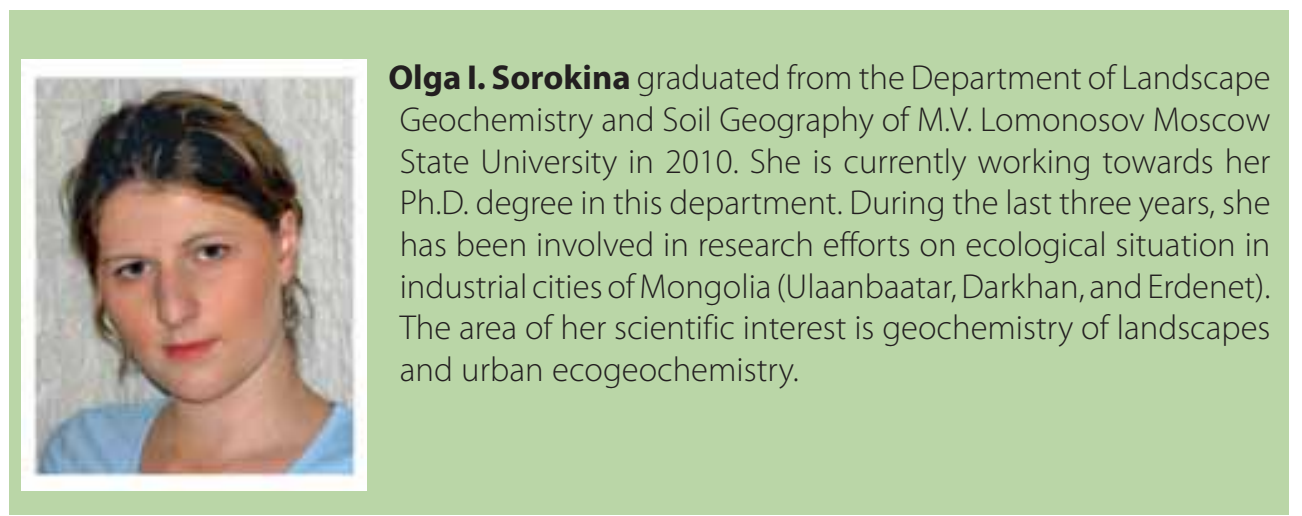




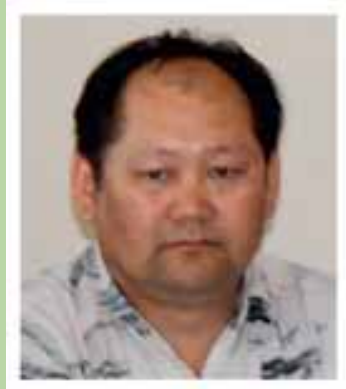

Sandag Enkh-Amgalan is Senior Researcher of the Institute of Geography of the Mongolian Academy of Sciences. He graduated from the Mongolian National University with Bachelor degree (1989). His Ph. D. dissertation was entitled "Ecological conditions of livestock management on pasture lands of the desert-steppe zone in Mongolia" (2000). The area of his research interest is in the fields of geography, social geography, geoecology, medical geography, and rural ecology. He is the author of approximately 70 scientific publications. 